\title{
HUBUNGAN POLA ASUH ORANG TUA TERHADAP KEPERCAYAAN DIRI PADA ANAK TUNA RUNGU DI SLB KOTA JAMBI
}

\author{
Elisa Murti Puspitaningrum \\ Email : elisa_mpn@ymail.com
}

\begin{abstract}
Deaf is a condition in which can't hear a sound. A deaf child is always suspicious to his environment, which often resulted in a lack of self-confidence so that proper parenting is required to enhance self-confidence of the children. With patience and personal understanding of the child, parents can help children have confidence in the environment. The purpose of this study was to determine the correlation between parenting pattern and self-confidence on deaf children at SLB Jambi City.

This reseach used descriptive correlation study with cross sectional design. Population was used 34 students at SLB Jambi City and the sampling technique used was total sampling. Data obtained by using a questionnaire on January 2018 This study used primary data in data collection and Chi Square Test in data analysis with the result $\alpha=0.05$

Results of study indicated that parents who implements democratic parenting for their children as many as 19 children (55,9\%), and who having good self-confidence was equal to sufficient one with total of 12 children $(35,3 \%)$. Based on Chi Square test there was a correlation between parenting pattern and self-confidence on deaf children at SLB Jambi City (p-value : 0,023)

It rrecommended for the school and cparents to improve guidance and education for their deaf children to establish better self-confidence
\end{abstract}

Keywords: Parenting pattern, Self-confidence, Deaf children Akademi Kebidanan Jakarta Mitra Sejahtera

Anak adalah anugerah yang diberikan oleh Tuhan, yang harus dijaga, dirawat, dan diberi bekal sebaikbaiknya bagaimanapun kondisi anak tersebut ketika dilahirkan. Orang tua akan merasa senang dan bahagia apabila anak yang dilahirkan dalam kondisi fisik dan psikis yang sempurna. Sebaliknya, orang tua akan merasa sedih apabila anak yang dilahirkan dengan kondisi yang tidak sempurna atau mengalami hambatan perkembangan (Lumbantobing, 2001).
Setelah dilahirkan, anak merupakan individu yang berbeda dalam satu rentang perubahan perkembangan yang dimulai dari bayi hingga remaja. Masa anak merupakan masa pertumbuhan dan perkembangan yang dimulai dari bayi (0-1 tahun), usia bermain/oddler (1-2,5 tahun), pra sekolah (2,5-5 tahun), usia sekolah (5-11 tahun) hingga remaja (11-18 tahun). Rentang ini berbeda antara anak satu dengan anak yang lain mengingat latar belakang anak yang berbeda misalnya kondisi fisik anak 
ketika lahir. Anak dapat lahir normal atau cacat, tentunya keadaan ini dapat mempengaruhi proses tumbuh kembang anak (Hidayat, 2005).

Beberapa kondisi anak dapat mempengaruhi tumbuh kembang anak misalnya adanya kelainan perkembangan fisik atau disebut cacat fisik (sumbing, juling, kaki bengkok, dan lain-lain). Adanya kelainan dalam perkembangan saraf seperti gangguan motorik, gangguan wicara, gangguan personal sosial, adanya kelainan perkembangan mental seperti retardasi mental, adanya kelainan perkembangan perilaku seperti hiperaktif, gangguan belajar, depresi dan lain-lain (Hidayat, 2005).

Seorang anak cacat sering mendapatkan perhatian dan pertolongan istimewa, tetapi bila ia telah menjadi remaja hal ini berkurang, padahal stress pada seorang cacat yang dialami pada masa akil balik lebih berat. Semua orang cacat (tuna netra, tuna rungu, retardasi mental, dan sebagainya) memerlukan lebih banyak bantuan pada masa adolesens. Gangguan pada pendengaran atau tuna rungu misalnya, harus sudah ditemukan pada masa anak, walaupun pemeriksaan dalam masa adolesens tetap diperlukan. Gangguan pada pendengaran atau tuna rungu sering terdapat sebagai latar belakang gangguan tingkah laku dan kepribadian (FKUI, 2007).

Penderita tuna rungu adalah mereka yang memiliki hambatan perkembangan indra pendengar. Tuna rungu tidak dapat mendengar suara atau bunyi. Dikarenakan tidak mampu mendengar suara atau bunyi, kemampuan berbicara pun kadang terganggu. Sebagaimana kita ketahui, ketrampilan berbicara sering kali ditentukan oleh seberapa sering seseorang mendengar orang lain berbicara. Akibatnya anak- anak tuna rungu sekaligus memiliki hambatan bicara dan menjadi bisu. Untuk berkomunikasi dengan orang lain, mereka menggunakan bahasa bibir atau bahasa isyarat (Geniofam, 2010).

Pada penderita tuna rungu, orang tua dan guru (yang memahami persoalan anak) sering merupakan manusia yang mempunyai ikatan emosi dengan tuna rungu. Dapat dikemukakan bahwa anak dengan cacat pendengaran selalu menaruh kecurigaan terhadap lingkungannya, yaitu kalau-kalau lingkungannya itu mencemoohkannya. Kecurigaan seperti inilah yang sering mengakibatkan sikap menyendiri, sikap memusuhi lingkungannya (nostile attitude) dan kecurigaannnya ini pula yang dapat menghambatnya mendapatkan tanggapan tentang diri sendiri (image of his ownself) wajar seperti yang seharusnya dimiliki oleh setiap dewasa. Sering tampak anak yang cacat pendengaran sangat melekat pada orang tua dan gurunya, karena terhadap mereka ia tidak perlu curiga dan ia juga merasa aman terhadap kemungkinan dicemoohkan. Sikap ini juga merupakan salah satu unsur penghambat perkembangan kepribadiaannya (FKUI, 2007).

Menurut Surya, 2007 menyatakan bahwa anak bermasalah dengan percaya dirinya yaitu anak tersebut selalu mengeluh tak punya kemampuan apaapa. Ketika belajar, anak mudah menyerah dan mengeluh sulit belajar. Jika diminta melakukan sesuatu, anak merasa takut untuk melakukan sesuatu, anak takut secara berlebihan dan merasa tak yakin dapat melakukannya. Kekurangan atau cacat yang dimiliki anak sering kali menjadi penghambat bagi anak berinteraksi dalam lingkungan pergaulannya. Anak kerapkali ditolak oleh kelompok bermainnya, karena cacatnya membuat teman bermainnya merasa 
risih dengan kekurangan yang dimiliki anak. Bahkan, kekurangan atau kecacatan anak tersebut menjadi bahan cemoohan mereka. Hal ini yang menyebabkan anak menjadi kurang percaya diri, dan orang tua yang mengetahui hal ini akan menaruh perhatian yang lebih pada anaknya.

Orang tua yang dapat menerima keadaan dirinya yang mempunyai anak tuna rungu akan tetap memberikan perhatian dan kasih sayang kepada anak tuna rungu seperti anak-anak lain yang dimilikinya. Diperjelas oleh Supriyapto (2001) bahwa orang tua dalam pola asuhnya harus dapat menciptakan relasi atau hubungan sehat dengan anak yang menyediakan kebutuhan fisik, serta keamanan bagi anak sehingga tercipta keluarga yang harmonis. Orang tua menyadari bahwa anak tuna rungu memerlukan tempat aman bagi perkembangan jiwa anak.

Bisono (2003) seorang psikolog dari Jakarta mengatakan bahwa orang tua yang mempunyai anak cacat fisik atau mental memerlukan kesabaran dalam membimbing anak penderita tuna rungu, selain itu juga diperlukan pemahaman yang mendalam mengenai pribadi anak. Dengan kesabaran dan pemahaman pribadi anak, orang tua dapat membantu anak memiliki kepercayaan diri dengan lingkungan.

Hakim (2002), mengemukakan bahwa keluarga merupakan lingkungan hidup pertama dan utama dalam kehidupan setiap orang, dan tentunya hal tersebut sangat berpengaruh terhadap pembentukan rasa percaya diri pada seseorang. Salah satu kondisi keluarga yang mempengaruhi kepercayaan diri seseorang adalah pola pendidikan keluarga. Pola pendidikan keluarga yang dimaksud adalah cara kedua orang tua mendidik anaknya atau dapat pula disebut sebagai pola asuh orang tua.

Menurut Suherman (2000), pola asuh orang tua dibagi menjadi 3 , yaitu pola asuh orang tua otoriter, pola asuh orang tua permisif, dan pola asuh orang tua demokratif. Pola asuh otoriter adalah pola asuh dimana orang tua berperan lebih dominan dalam pengambilan keputusan dan pendapat anak cenderung kurang atau tidak diperhitungkan oleh orang tua. Pola asuh permisif adalah pola asuh dimana anak dibiarkan untuk bertindak sesuai keinginannya sendiri tanpa ada batasan dan tanpa pernah diberikan pengetahuan mana yang baik dan mana yang buruk oleh orang tuanya. Pola asuh demokratis adalah pola asuh dimana ada saat anak untuk mengeluarkan pendapat kepada orang tua begitu pula orang tua mau berusaha untuk menerima pendapat anaknya.

Menurut Geniofam (2010), menyatakan bahwa peran dan tingkah laku orang tua merupakan cerminan untuk pembentukan kepribadian yang baik, sedangkan kepribadian yang baik itu didasari oleh kepercayaan diri anak yang baik pula. Pada anak tuna rungu yang mempunyai rasa tidak percaya diri terhadap kekurangan yang dimilikinya memerlukan pola penga-suhan orang tua yang baik agar dapat mengembalikan rasa percaya diri anak tuna rungu dengan memberikan kesempatan pada anak tuna rungu untuk berpendapat, mengungkapkan suatu keinginannya, melakukan hal yang dikehendakinya tanpa ada kekangan dari pihak manapun, dan selalu memberikan cinta, kasih sayang serta perhatian yang penuh dari orang tua.

Berdasarkan wawancara kepada 5 orang tua murid di SLB Kota Jambi menyatakan bahwa mengalami kesu- 
litan dalam mengasuh anaknya, yaitu anak terkadang malu terhadap kecacatan yang dideritanya, sehingga mereka sulit bergaul. Setelah dilakukan wawancara diperoleh hasil bahwa 2 orang $(40 \%)$ mengatakan dalam segala hal apapun dalam kehidupannya anak tersebut diatur oleh orang tuanya, yang mengakibatkan kepercayaan diri anak kurang, mereka selalu meminta bantuan pada orang tuanya jika akan melakukan hal apapun, mereka cenderung takut melakukan kesalahan. 1 orang $(20 \%)$ mengatakan anak diberikan kebebasan dalam mengatur kehidupannya sendiri, orang tua cenderung tidak memperhatikan dan cuek atas perilaku anaknya sehingga anak terlalu percaya diri yang mengakibatkan tidak adanya tanggung jawab, dan disiplin pada anak. 2 orang (40\%) mengatakan memberikan kebebasan pada anaknya dalam memilih kehidupannya tetapi orang tua tersebut masih memantau perkembangan anaknya sehingga anak memiliki keper-cayaan diri yang baik, dapat bergaul dengan siapapun, dan dapat beradaptasi dengan lingkungan dengan baik pula.

Dari uraian diatas dapat diketahui bahwa orang tua mempunyai pengaruh yang besar terhadap perkembangan anak tuna rungu. Orang tua sebagai orang yang terdekat dalam kehidupan anak yang tuna rungu, dimana dapat membentuk kepercayaan diri anak tersebut. Sikap yang penuh cinta kasih dan penerimaan dalam bentuk apapun keadaan anak merupakan hal yang dibutuhkan oleh anak.

\section{METODE PENELITIAN}

Desain penelitian yang digunakan adalah penelitian deskriptif korelasi, yang bertujuan untuk menjelaskan pola asuh orang tua terhadap kepercayaan diri pada anak tuna rungu di SLB Kota Jambi. Populasi dalam penelitian ini adalah siswa-siswi di SLB yang menderita tunarungu berjumlah 34 orang. Sampel berjumlah 34 responden. Teknik pengambilan sampel yang digunakan dalam penelitian ini adalah Total Population. Penelitian dilakukan pada bulan Januari 2018. Pengumpulan data menggunakan data primer, yaitu pengisian kuesioner dan analisis data menggunakan Chi Square dengan $\alpha=$ 0,05 .

\section{HASIL DAN PEMBAHASAN}

\section{Pola Asuh Orang Tua}

Distribusi frekuensi berdasarkan Pengetahuan Orang Tua disajikan pada tabel berikut ini :

Tabel 1.

Distribusi Frekuensi Berdasarkan Pola Asuh Orang Tua pada Anak Tuna Rungu di SLB Kota Jambi.

\begin{tabular}{llll}
\hline No & Pola Asuh & \multicolumn{2}{l}{ Distribusi } \\
\cline { 3 - 4 } & & $\mathrm{F}$ & $\%$ \\
\hline 1. & Permisif & 0 & 0 \\
2. & Demokratis & 19 & 55.9 \\
3. & Otoriter & 15 & 44.1 \\
\hline Jumlah & 34 & 100 \\
\hline
\end{tabular}

Berdasarkan tabel 1 maka dapat disimpulkan bahwa mayoritas responden memiliki pola asuh demokratis, yaitu 19 responden $(55,9 \%)$ dan yang memiliki pola asuh otoriter sebanyak 15 responden $(44,1 \%)$. Hal ini dilihat dari hasil pengisian responden bahwa sebagian besar orang tua memberi kebebasan untuk memilih sesuatu yang diinginkan anak, orang tua selalu memimbing anak dengan sabar tanpa harus marah, selalu meluangkan waktu 
berkumpul dengan keluarga, dan jarang marah kecuali anak berbuat kesalahan.

Pola asuh merupakan sikap orang tua dalam berinteraksi dengan anakanaknya. Sikap orang tua ini meliputi cara orang tua menunjukan otoritasnya, dan cara orang tua memberikan perhatian serta tanggapan terhadap anaknya. Dalam melakukan tugas-tugas perkembangannya, individu banyak dipengaruhi oleh peranan orang tua tersebut. Peranan orang tua itu memberikan lingkungan yang memung-kinkan anak dapat menyelesaikan tugas-tugas perkembangannya (Koch dalam Saripah, 2008).

Pola asuh demokratis meru-pakan dimana teknik-teknik asuhan orang tua yang demokratis akan me-numbuhkan keyakinan dan kepercayaan diri maupun mendorong tindakan-tindakan mandiri membuat keputusan sendiri akan berakibat munculnya tingkah laku mandiri yang bertanggung jawab. Pola asuh demo-kratis adalah pola asuh yang memprio-ritaskan kepentingan anak, akan tetapi tidak ragu-ragu mengendalikan mereka. Orang tua dengan pola asuh ini bersikap rasional, selalu mendasari tindakannya pada rasio atau pemikiran-pemikiran. Orang tua tipe ini juga bersikap realitis terhadap kemampuan anak, tidak ber-harap yang berlebihan yang melampaui kemampuan anak. Orang tua tipe ini juga memberikan kebebasan kepada anak untuk memilih dan melakukan suatu tindakan, dan pendekatannya kepada anak bersifat hangat (Baumrind dan Black dalam Saripah, 2008).

Menurut Supartini (2004), pola asuh demokratis akan menghasilkan karakteristik anak-anak yang mandiri, dapat mengontrol diri, mempunyai hubungan baik dengan teman, mampu menghadapi stress, mempunyai minat terhadap hal-hal yang baru dan kooperatif terhadap orang lain.

Pola asuh otoriter merupakan pola asuh yang kurang efektif dalam mengasuh anak tuna rungu, karena dengan keterbatasannya dalam mendengar, biasanya anak tuna rungu rasa ingin tahunya lebih besar, karena secara mental mereka itu normal, sama dengan anak normal lainnya. Orang tua yang menerapkan pola asuh otoriter biasanya cenderung memperlakukan anaknya seperti boneka, jadi segala kehidupannya diatur oleh orang tuanya, sehingga keperayaan diri anak menjadi kurang. Hal ini sesuai dengan pengisian kuesioner responden bahwa masih ada beberapa orang tua yang selalu menutut anaknya untuk selalu benar dalam melakukan tindakan, seperti pekerjaan rumah, anak jarang diperbolehkan untuk bermain diluar rumah, dan mewajibkan anak untuk selalu patuh dengan peraturan orang tua.

Hal ini tidak sesuai dengan pendapat Bisono (2003) mengatakan bahwa orang tua yang mempunyai anak cacat fisik atau mental memerlukan kesabaran dalam membimbing anak penderita tuna rungu, selain itu juga diperlukan pemahaman yang mendalam mengenai pribadi anak.

\section{Kepercayaan Diri pada Anak Tuna Rungu}

Distribusi frekuensi berdasarkan Kepercayaan Diri Anak disajikan pada tabel berikut ini :

\section{Tabel 2.}

Distribusi Frekuensi Berdasarkan Kepercayaan Diri pada Anak Tuna Rungu di SLB Kota Jambi 


\begin{tabular}{lllll}
\hline No & Motivasi & \multicolumn{2}{l}{ Distribusi } & \\
\cline { 3 - 5 } & & F & $\%$ & C \\
\hline 1 & Kurang & 10 & 29.4 & k \\
2 & Cukup & 12 & 35.3 & r \\
3 & Baik & 12 & 35.3 & r \\
\hline Jumlah & 34 & 100 & t \\
\hline
\end{tabular}

Kepercayaan diri anak tuna rungu dengan anak yang normal berbeda karena keterbatasannya anak tuna rungu dalam mendengar membuat mereka sukar untuk bergaul dengan teman sebayanya yang normal, hal ini diperlukan dukungan orang tua dan

Berdasarkan tabel 2 maka dapat disimpulkan bahwa mayoritas responden memiliki kepercayaan diri yang cukup dan baik, yaitu masing-masing 12 responden $(35,3 \%)$ dan yang memiliki kepercayaan diri kurang sebanyak 10 responden $(29,4 \%)$.

Kepercayaan diri adalah suatu perasaan positif yang ada dalam diri seseorang yang berupa keyakinan dan kepercayaan terhadap kemampuan dan potensi yang dimilikinya, serta dengan kemampuan dan potensinya tersebut dia merasa mampu untuk mengerjakan segala tugasnya dengan baik dan untuk meraih tujuan hidupnya (Davies, 2004).

Kepercayaan diri yang dialami oleh anak tuna rungu di SLB Kota Jambi ini adalah beberapa anak ada yang yakin dengan kemampuannya di sekolah, mampu melakukan tugas nya tanpa didampingi orang tua, tidak pernah merepotkan orang lain dan menerima kondisi fisik yang dialaminya.

Percaya diri tidak begitu saja melekat pada anak. Kemampuan percaya diri bukan merupakan bawaan lahir atau keturunan anak. Seorang anak dilahirkan dengan segala kelebihannya dan kekurangannya, lengkap dengan bakat, potensi, dan rezekinya. Kebanyakan anak yang terlahir dalam keadaan cacat misalnya tuna rungu, mempunyai perasaaan malu atau tidak percaya diri untuk berinteraksi sosial dengan teman sebayanya. Perasaan tidak percaya diri yang dirasakannya itu akan menghambat perbaikan (kesembuhan) pada si anak (Geniofam, 2010). keluarga dalam mengembangkan rasa kepercayaan diri anak tuna rungu agar menjadi lebih baik

\section{Hubungan Pola Asuh Orangtua dengan Kepercayaan Diri pada Anak Tuna Rungu di SLB Kota Jambi}

Tabel 3.

Hubungan Pola Asuh Orangtua terhadap Kepercayaan Diri pada Anak Tuna Rungu di SLB Kota Jambi

\begin{tabular}{|c|c|c|c|c|c|c|c|c|}
\hline \multirow{3}{*}{$\begin{array}{l}\text { Pola Asuh } \\
\text { Orang tua }\end{array}$} & \multicolumn{5}{|c|}{ Kepercayaan Diri } & \multirow{2}{*}{ Total } & \multirow{3}{*}{$X^{2}$} & \multirow{3}{*}{$\begin{array}{l}\mathrm{p}- \\
\text { valu } \\
\mathrm{e}\end{array}$} \\
\hline & Kurang & & kup & $\mathrm{Bc}$ & & & & \\
\hline & $\mathrm{F} \%$ & $\mathrm{~F}$ & $\%$ & f & $\%$ & F \% & & \\
\hline Permisif & 0 & 0 & 0 & 0 & 0 & $\begin{array}{ll}0 & 0\end{array}$ & 7,5 & 0,02 \\
\hline Demokratis & 210,5 & 8 & 42,1 & 9 & 47,4 & 19100 & 67 & 3 \\
\hline Otoriter & 853,3 & 4 & 26,7 & 3 & 20,0 & 15100 & & \\
\hline Total & 1029,4 & 12 & 35,3 & 12 & 35,3 & 34100 & & \\
\hline
\end{tabular}

Berdasarkan tabel 3 maka dapat disimpulkan bahwa orang tua yang menerapkan pola asuh demokratis tingkat kepercayaan diri anaknya baik yaitu sejumlah $47,4 \%$, sedangkan orang tua yang menerapkan pola asuh otoriter tingkat kepercayaan diri anaknya kurang yaitu sejumlah 53,3\%.

Berdasarkan uji Chi Square diperoleh nilai $p$-values 0,023 . Oleh karena $p$-value $0,023<0,05$ sehingga dapat disimpulkan bahwa ada hubungan yang signifikan antara pola asuh orang tua dengan kepercayaan diri pada anak tuna rungu SLB Kota Jambi. Hal ini menunjukan bahwa orang tua yang menerapkan pola asuh demokratis 
anaknya berpeluang lebih besar mempunyai kepercayaan diri yang baik dibandingkan orang tua yang menerapkan pola asuh otoriter.

Adanya korelasi tersebut membuktikan bahwa pola asuh mengambil peranan penting dalam perkembangan dan pembentukan pribadi seorang anak. Menurut Santrock (2003), pola asuh demokratis dapat membentuk tumbuhnya rasa percaya diri yang baik pada anak karena anak tersebut diberikan kesempatan untuk mengambil keputusannya sendiri, diberikan kesempatan untuk mengembangkan kemampuannya dan keputusan yang diambil sendirinya tepat dengan sendirinya rasa percaya diri yang dimiliki anak tersebut akan meningkat.

Meskipun banyak faktor yang mempengaruhi kepercayaan diri seseorang, namun faktor pola asuh orang tua merupakan faktor yang mendasar bagi pembentukan rasa kepercayaan diri anak. Sikap orang tua yang menunjukan kasih, perhatian, penerimaan, cinta dan kasih sayang serta kelekatan emosional yang tulus dengan anak, akan membangkitkan rasa percaya diri pada anak tersebut. Agar anak dapat berkembang dengan baik, maka orang tua dalam mendidik anakanaknya perlu menerapkan pola asuh yang tepat, baik dan sesuai. Pola asuh orang tua merupakan cerminan bagaimana interaksi antara orang tua dengan anaknya dapat terwujud.

Menurut Geniofam (2010), menyatakan bahwa peran dan tingkah laku orang tua merupakan cerminan untuk pembentukan kepribadian yang baik, sedangkan kepribadian yang baik itu didasari oleh kepercayaan diri anak yang baik pula. Pada anak tuna rungu yang mempunyai rasa tidak percaya diri terhadap kekurangan yang dimi- likinya memerlukan pola pengasuhan orang tua yang baik agar dapat mengembalikan rasa percaya diri anak tuna rungu dengan memberikan kesempatan pada anak tuna rungu untuk berpendapat, mengungkapkan suatu keinginannya, melakukan hal yang dikehendakinya tanpa ada kekangan dari pihak manapun, dan selalu memberikan cinta, kasih sayang serta perhatian yang penuh dari orang tua.

Baumrind dalam handayani (2001), mengungkapkan bahwa pola asuh orang tua mempengaruhi kepercayaan diri pada anak. Semakin baik pola asuh orang tua yang diterapkan maka akan semakin tinggi tingkat kepercayaan diri pada anak, begitu juga sebaliknya jika semakin jelek pola asuh orang tua maka semakin rendah tingkat kepercayaan diri anak. Agar anak dapat berkembang dengan baik, maka orang tua dalam mendidik anak-anaknya perlu menerapkan pola asuh yang tepat, baik dan sesuai. Pola asuh orang tua merupakan cerminan bagaimana interaksi antara orang tua dengan anaknya dapat terwujud.

\section{KESIMPULAN DAN SARAN}

Berdasarkan hasil penelitian diperoleh hasil bahwa mayoritas responden memiliki pola asuh demokratis memiliki kepercayaan diri baik, yaitu 9 responden $(47,7 \%)$ dan responden yang memiliki pola asuh otoriter memiliki kepercayaan diri yang kurang baik, yaitu 8 responden $(53,8 \%)$. Berdasarkan uji Chi-Square, ada hubungan antara pola asuh orang tua terhadap kepercayaan diri pada anak tuna rungu di SLB Kota Jambi. Disarankan kepada pihak sekolah dan orang tua untuk meningkatkan bimbingan dan pendidikan pada anak tuna rungu untuk 
membentuk kepercayaan diri yang lebih baik

\section{REFERENSI}

Davies, P. 2004. Meningkatkan Rasa Percaya Diri. Alih Bahasa Saut Pasaribu. Yogyakarta : Torrent Books

FKUI. 2007. Ilmu Kesehatan Anak 1. Jakarta : Infomedika Jakarta

Geniofam. 2010. Mengasuh dan mensukseskan anak berkebutuhan khusus. Jogjakarta : Garailmu

Hakim, T. 2002. Mengatasi Rasa Tidak Percaya Diri. Jakarta: Puspa Swara.

Handayani, A. 2001. Hubungan Pola Asuh Demokratis Orang Tua dalam Masalah Kelompok. Skripsi . Yogyakarta : UGM

Hidayat, Alimul, A.A. 2005. Pengantar Ilmu Keperawatan Anak 1. Jakarta : Salemba Medika

Lumbantobing, S.M. 2001. Anak dengan Mental Terbelakang. Jakarta : FKUI

Santrock. John. 2003. Adolescence. Perkembangan Remaja. Edisi ke Enam. Jakarta : Erlangga

Saripah. 2008. Bimbingan bagi orang tua dalam penerapan pola asuh untuk meningkatkan kematangan social anak

Suherman. 2000. Buku Saku Perkembangan Anak. Jakarta : EGC

Supartini, Y. 2004. Konsep Dasar Keperawatan Anak. Jakarta: EGC. Surya, drs Hendra. 2007. Percaya diri itu penting. Jakarta : PT Elex Media Komputindo 